\title{
THE RIGHT TO A JURY TRIAL
}

IN FELA ACTIONS IN STATE COURTS

\section{JACK H. CHAMBERS*}

Mr. Justice Frankfurter dissenting in Brown v. Western $R y$. of Ala." said of the use of the terms "substantive" and "procedural" in determining whether state or federal law applied:

"They derive content from the functions they serve here [in FELA actions in state courts] in precisely the same way in which we have applied them in reverse situations [federal trials of diversity cases involving non-federal rights under Erie v. Tompkins]."

The accuracy of this statement, that the substantive-procedural dividing line is the same for cases of trial of Federal Employers' Liability Act rights in state courts as in federal court trials of non-federal rights in diversity cases, ${ }^{2}$ with particular regard to the right to a jury, is the subject of inquiry here. As a further development of this subject we must also consider the extent to which state rules may affect the right to jury in federal courts, and, conversely, what control the federal government may exercise over states' uses of the jury.

As a starting point, it may be well to note that in both federal diversity cases and Liability Act trials in state courts, the courts have generally accepted substantive and procedural tests as an adequate generalization of the rule to be applied when deciding whether state or federal law is to be applied to a given subject. Both the opinion of the court and the dissent speak of this division in Erie v. Tompkins. ${ }^{3}$ And the great majority of courts have readily ac-

* 2d year law student, Duke University; A.B. Duke, 1951.

1338 U.S. 294,301 (1949).

a "Diversity cases" is used here as a convenient term representing all types of cases in which the doctrine of Erie $\nabla$. Tompkins requires that state law be applied in the federal courts. That this doctrine applies to cases other than diversity, see Snepp, The Law Applied in the Federal Courts, $13 \mathrm{Lu}$ W \& Contenr. ProB. 165, 168 (1948).

s 304 U.S. 64 (1938). 
cepted this division as representing the dividing line in diversity cases. ${ }^{4}$ In FELA cases being tried in state courts this same distinction has been frequently discussed by the courts in their decisions as to whether state or federal rules prevail. 5

Not only have the same labels been applied in the two types of situations, but also the rulings on whether a particular matter is procedural or substantive have been the same generally whether the question arose out of a diversity action or a state trial of FELA rights. Thus, the question of who bears the burden of proof has been held to be substantive, both in diversity cases, ${ }^{6}$ and in actions under the Liability Act. ${ }^{7}$ Admissability of evidence is a procedural question to be decided by the law of the forum in both types of cases. ${ }^{8}$ And in both Federal Employers' Liability actions and diversity cases the question of what constitutes negligence has been ruled to be a substantive one. ${ }^{9}$

Though the procedural-substantive line of division may be valid in determining what law applies for many "questions, is that line of division valid in determining the controlling law on the right to a jury and the division of functions between judge and jury?

Stoner v. New York Life Ins. Co. ${ }^{10}$ involved an accident case brought to the federal courts on diversity. There, before the case was removed to the United States District Court, the Kansas City Court of Appeals had twice decided that the evidence in the case was sufficient to go to the

\footnotetext{
- See cases collected in 28 U.S.C.A. § 1652.

- See cases collected in 45 U.S.C.A. \& 51, in particular notes 502-504.

- New Orleans \& N. E. R. Co. v. Harris, 247 U.S. 367 (1918).

7 Palmer v. Hoffman, 318 U.S. 109 (1943); Cittes Service Oil v. Dunlap, 308 U.S. 208 (1939).

- In diversity cases see Waider v. Chicago, R.I. \& P.R. Co., 10 F.R.D. 376 (S. D. Iowa 1950); Franzen v. E. I. Du Pont De Nemours, 51 F.Supp. 578 (D. N.J. 1943). In FELAA actions in state courts, Central Vermont Ry. Co., v. White, 238 U.S. 507 (1915); Lavender v. Kurn, 327 U.S. 645 (1946). of Fed. Rule 43(a).

- In diversity cases, Southern Pacific Co. v. Haight, 126 F.2d 900 (9th Cir. 1942); Young v. Julian, 97 F. Supp. (D. Del. 1951). In FELA actions, Urie $\nabla$. Thompson, 337 U.S. 163 (1949).

${ }^{10} 311$ U.S. 464 (1940).
} 
jury, ${ }^{11}$ the United States Supreme Court ruled that the federal District Court had erred in granting a directed verdict in a trial of the same issue on the same evidence which had been before the state court. Though the Court does not discuss the substantive-procedural division, the decision appears to be authority for the view that the sufficiency of evidence in diversity cases is a substantive question to be decided in accordance with state law. However, the peculiar fact situation may explain the case, and possibly it "should be regarded as a novel application of the doctrine of the law of the case." "12

Although the Stoner case may not have established beyond question that the rule as to sufficiency of evidence in diversity cases is a substantive one, the question has been settled as substantive in FELA cases in state courts by Brady v. Southern Ry. Co.13 There the United States Supreme Court ruled that the North Carolina Supreme Court had erred in applying the state standard of the sufficiency of evidence instead of the federal standard in a state trial of a FELA right.

This ruling that sufficiency of evidence is a substantive questions covers only a part of the general field of division of functions between judge and jury, and can hardly be said to stand for the general proposition that the entire field of division between judge and jury is a matter of sub-

I1 The first action, 90 S.W.2d 784 (Kan. City Ct. Ap. 1936). The sec. ond action, 232 Mo.App. 1048, 114 S.W.2d 167 (1938).

In April, 1934, Stoner brought suit in a Missouri state court to recover disability payments due from the New York Life Ins. Co. The trial judge rendered a directed verdict for the defendant. On appeal the Kansas City Court of Appeals ruled that the plaintiff had presented sufficient evidence to take the case to the jury. In 1936, while this case was still pending, plaintiff brought suit for other disability benefits which had accrued since commencement of the first action. This time the plaintiff was successful in the lower court and the defendant appealed. The result was again reversed (because of incorrect instructions to the jury), but the Kansas City Court of Appeals again ruled that plaintiff's evidence had established a jury question. While both these actions were pending the Insurance Co. brought this suit in the federal district court for a declaratory judgment ruling that the Company was no longer required to make disability payments to stoner.

12 Moore, Federal Practice, p. 29 (1st ed., vol. 3, 1950 supp.).

13320 U.S. 476 (1943). 
stantive law: In Dice v. Akron, Canton \& Youngstown $R$. Co. ${ }^{14}$ the court has gone far toward settling that proposition. The case involved an action brought in the Ohio courts under the FELA. The trial judge himself decided the issue of fraud in obtaining a release, instead of submitting that issue to the jury. This is in accordance with the Ohio practiee, but not with the federal rule. ${ }^{15}$ The result was upheld by the Ohio Supreme Court, ${ }^{16}$ but reversed by the United States Supreme Court in a five-to-four decision. Reversal was based in part on the error of the Ohio Court in applying the state rather than the federal standard as to the validity of releases (and in this the minority concurred). But the majority opinion by Mr. Justice Black went further and held that there was also error in withholding the issue of fraud from the jury. The language of the opinion indicates with certainty that the right to a jury trial is a substantive right:

"[T] he right to trial by jury is too substantial a part of the rights accorded by the [FEL] Act to permit it to be classified as a 'mere local rule of procedure' for denial in the manner that Ohio has here used."17

The minority opinion regards the majority as holding the right to a jury trial a substantive one, at least under the Employers' Liability Act:

"The fact that Congress authorized actions under the Federal Employers' Liability Act to be brought in State as well as in Federal courts seems a strange basis for the inference that Congress overrode State procedural arrangements controlling all other negligence suits in a State, by imposing upon State courts to which plaintiffs choose to go the rules prevailing in the Federal courts regarding juries."18

\footnotetext{
14 342 U.S. 359 (1952).

16 For the Federal rule, see note 14, supra, at p. 362. For the ohio rule, see Dice v. Akron, C. \& Y. R. Oo. 155 Ohio St. 185, 98 N.E. $2 d$ 301, (1051). ${ }^{16}$ Dice v. Akron, C. \& Y. R. Co., 155 Ohio St. 185, 98 N.E.2d 301, (1951).

17 Supra, note 14 at 363 .

18 Ibid. at 368 .
} 
Before discussing at any length the effect of the Dice case, one more case must be considered. Herron v. Southern Pacific Co. ${ }^{10}$ was an action brought on the basis of diversity in a Federal District Court as a result of an automobiletrain accident in Arizona. The Arizona Constitution provided that in all cases involving contributory negligence that issue was to be submitted to the jury. ${ }^{20}$ Yet, the district judge decided the question of contributory negligence without sending it to the jury, and this action was affirmed by the United States Supreme Court. Since this case arose in 1931, it might have been argued that the right to a jury trial on the issue of contributory negligence was a mere procedural right and, therefore, the Conformity Act ${ }^{21}$ required that the issue be submitted to the jury. But no such contention was made. Counsel for the appellant chose to argue that the right to a jury was a matter of substance and, under the Rules of Decision Act, ${ }^{22}$ the state constitutional provision was controlling. The opinion of the Court by Chief Justice Hughes shows that the appellant was wise in not arguing that the question was procedural, and agrees that the matter involved is substantive:

"The rule of the Arizona Constitution cannot be regarded as one that relates merely to practice or to a 'form' or 'mode of proceeding.' The provision 'cuts deep into the right, observed at common law, by which defendant can obtain a decision by the court, upon a proven state of facts." "23

However, the Court felt the state rule could not be applied in the federal courts on this question because the federal courts are bound by the Seventh Amendment to apply their own separation of functions between judge and jury:

"In a trial by jury in a federal court, the judge is not a mere moderator, but is the governor of the trial for the purpose of assuming its proper con-

\footnotetext{
10283 U.S. 91 (1931).

20 ArIz. Const., Art. 18, $\$ 5$.

a 28 U.S.C. $\$ 724$.

$\approx 28$ U.S.C. \$ 725.

$\approx$ Supra, note 19 at 93.
} 
duct and of determining questions of law. This discharge of the judicial function as at common law is an essential factor in the process for which the Federal Constitution provides." 24

The cases discussed, when considered as a group, indicate that the line between substance and procedure is the same in this field for both diversity and FELA cases. The division of functions between judge and jury is, by these cases, a matter of substantive law. But, as the Herron case shows, division of functions in federal courts is controlled by the Seventh Amendment, and may not be changed by state law even though the substantive-procedural division would call for a division of functions in accordance with state law. If this conclusion is correct, the result in the Stoner case would appear unsound. Even if that decision is 'law of the case,' the result therein, according to the Herron case, should have been governed by the Seventh Amendment. There are two possible explanations for the Stoner decision. First, the Seventh Amendment was apparently not argued by counsel and, possibly, was never considered by the Court as a part of the case. The second possible, if tenuous, explanation is that the Court drew a distinction between cases where, as in Herron, the state completely eliminates the dividing line between functions of judge and jury by providing that a certain question shall lie solely in the province of only one of the two; and cases where, as in Stoner, a state still provides a dividing line between judge and jury questions on certain functions, but determines that line according to state, rather than federal, practice. The former of the two explanations seems more plausible, but only by the rationale of the second possibility may the decisions in both Herron and Stoner be accepted as valid. In view of the fact that neither argument of counsel nor the opinion of the court in the Stoner case mentions the Seventh Amendment, it seems better to concede that the Amendment was overlooked in the case and the decision, therefore, rested on false grounds.

Since the Seventh Amendment seems to prevent state

24 Ibid. at 95. 
control of the federal use of juries, the question naturally suggested is whether there is anything which forbids the federal government to force rules concerning use of the jury on the states. There are no federal constitutional requirements or limitations on state juries in eivil actions. In the words of Mr. Justice Holmes:

"There is nothing in the Constitution of the United
States or its Amendments that requires a State to
maintain the line with which we are familiar be-
tween the functions of the jury and those of the
Court. It may do away with the jury altogether."

There being no Constitutional requirement of state use of the jury in civil actions, we may better understand any possible limitations on federal control by first examining the extent of the federal requirement that state courts take jurisdiction of cases arising under the Employers' Liability Act. The Act, itself generally justifiable under the Commerce Clause, provides that state courts shall have concurrent jurisdiction with the federal courts of cases arising under the Act. ${ }^{26}$ In Mondou v. New York, N. H. \& H. R. $C o .^{27}$ the Supreme Court decided affirmatively the question:

"[W] hether rights arising under the congressional act may be enforced, as of right, in the courts of the states when their jurisdiction, as prescribed by local laws, is adequate to the occasion." 28

25 Chicago, R. I. \& P. Ry. Co. v. Cole, 251 U.S. 54, 56 (1919).

$\approx 45$ U.S.C.A. \& 56.

27223 U.S. 1, 55 (1912).

$\approx$ It must be made explicit that the Court did not consider the question whether Congress might validily force any new type of jurisdiction, or a different mode of procedure, on the state courts: "[T] here is not here involved any attempt by Congress to enlarge or regulate the jurisdiction of state courts or to control or affect their modes of procedure, but only a question of the duty of such a court, when its ordinary jurisdiction is prescribed by local laws is appropriate . . . to take cognizance of an action to enforce a right of civil recovery arising under the act of Congress ..." The decision, then, is limited to a construction of the FELA, and does not involve the constitutional question regarding the right of the federal government to control and regulate state courts. Similarly, it is not the purpose of this article to consider the possible restrictions placed on the federal government in this field by the Tenth Amendment. 
However, the Act does not require state courts to take jurisdiction of FELA cases if those courts would not, under the law of the state, have jurisdiction over similar cases involving non-federal rights. ${ }^{20}$ The requirement is simply that a state may not refuse to take jurisdiction of a case because the suit is brought under federal law. ${ }^{30}$

In Minneapolis \& St. L. R. Co. v. Bombolis ${ }^{31}$ the court decided that the right to a Seventh Amendment jury is not a right which necessarily attaches to federally created rights. ${ }^{32}$ The question involved was whether Minnesota could validly provide for jury decisions by only five-sixths of the jury in actions arising under the FELA. The approval given the Minnesota system has generally been accepted to stand for the proposition that states do not have to provide a jury system for FELA actions different from the system used by the state for local negligence cases. $^{33}$ The net effect of the doctrines of Mondou, supra, and Bombolis is to establish the doctrine that state courts must provide the same facilities for trials of FELA rights which local rules require in ordinary negligence cases, no more or less.

What effect the Dice case ${ }^{34}$ has on this doctrine in its operation on the question of what type jury a state must

$\approx$ Douglas v. New York, N. H. \& H. R. Co., 279 U.S. 377 (1929).

so McKnett v. St.I. \& S.F. Ry. Co., 292 U.S. 230 (1934).

at 241 U.S. 211 (1918).

32 The Court did not pass on the argument that the FELA shows an intent on the part of Congress to require state courts to follow federal rules regarding the use of juries. Other cases indicate that the Court may be willing to attribute such an intent to Congress: "But the United States courts have uniformly held that as a matter of general law the burden of proving contributory negligence is on the defend. ant... Congress in passing the Federal Employers' Liability Act evidently intended that the Federal statute should be construed in the light of these and other decisions of the Federal courts." Central Ver. mont Ry. C. v. White, supra, note 8 at 512. "The right to trial by jury is ' $a$ basic and fundamental feature of our system of federal jurispru. dence' ... It is part and parcel of the remedy afforded railroad workers under the Empioyers' Liability Act . . . To deprive these workers of the benefits of a jury trial in close or doubtful cases is to take away a goodly portion of the relief which Congress has afforded them." Balley v. Central Vermont Ry. Co., 319 U.S. 350, 354 (1943).

3 Frankfurter, dissenting, in Dice v. Akron, supra, note 14.

st Supra, at note 14. 
provide, and when a jury must be provided, is a question of considerable importance. The minority in the Dice case suggest that the effect of that opinion is to overrule Bombolis. ${ }^{35}$ Does this mean that states must provide for juries similar to those used by the federal courts in state trials of FELA rights? Such a result would have far-reaching consequences since twenty-one states now provide for verdicts by other than a unanimous jury. ${ }^{36}$ The Dice majority opinion is probably not intended to go this far, and even the minority opinion does not suggest that the case is of this scope. It seems more plausible to interpret the majority in Dice to say that where a state does provide a jury as one of the facilities to be used in local negligence cases (and thus in FELA trials), the question of when that facility is to be used in FELA cases is a substantive question to be decided by federal law. This result is in accordance with the procedural-substantive line which we have found to be drawn by the cases. Moreover, this would seem to be a logical result of the Court's apparent desire in recent years to maintain federal control over the submission of cases to the jury. ${ }^{37} \mathrm{Mr}$. Justice Black's language supports this interpretation of the case:

"It is contended that since a state may consistently with the Federal Constitution provide for trial of cases under the Act by a nonunanimous verdict . . . Ohio may lawfully eliminate trial by jury as to one phase of fraud while allowing jury trial as to all other issues raised. The Bombolis case might be more in point had Ohio abolished trial by jury in all negligence cases including those arising under the federal Act. But Ohio has not done this. It has provided jury trials for cases arising under the federal Act but seeks to single out one phase of the question of fraudulent releases for determination by a judge rather than by a jury." 38

35 Ibid, at 368

so Bouchelle, Requirement of Consent of Three-Fourths of July to Verdicts in Civil Actions, Abolishing Law of Unanimous Consent, 48 W.VA.L.Q. 149, 154 (1942).

37 Enlargement of the Jury's Frunction In FELA Cases, 44 IrL.L.REV. 854 (1950).

s Supra, note 14 at 363 . 
A reconsideration of our conclusions requires that we again start with the basic dividing line between substantive and procedural questions as used to decide whether state or federal laws governs a particular question. This substantive-procedural line has been drawn in the same place for questions involving federal trial of diversity cases. The cases show the division of functions between judge and jury and the right to a jury have both been decided to be matters of substantive law. From this it would follow that in diversity cases the federal courts would apply state rules as to the function of judge and jury. But here, we have found, the substantive-procedural line gives away to the Seventh Amendment requirement controlling federal use of juries. As to federal control, under the FELA, of states' uses of juries in actions involving rights created by the Act by use of the substantive-procedural method of deciding whose law controls, we have decided that the state itself may decide what facilities it wishes to provide in negligence actions, and thus for FELA actions. But once a state has decided the facilities to be provided, federal law will control the use of those facilities, at least in questions involving the division of functions between judge and jury. 